\title{
Familial exudative vitreoretinopathy in a patient with choroidal coloboma
}

\author{
Vinod Kumar, Srikanta Kumar Padhy
}

Ophthalmology, Dr Rajendra Prasad Centre for Ophthalmic sciences, AllMS, New Delhi, Delhi, India

\section{Correspondence to Dr Vinod Kumar, drvinod_agg@yahoo.com}

Accepted 30 January 2019
Check for updates

(C) BMJ Publishing Group Limited 2019. No commercial re-use. See rights and permissions. Published by BMJ.

\footnotetext{
To cite: Kumar $V_{\text {, }}$

Padhy SK. BMJ Case

Rep 2019;12:e228711.

doi:10.1136/bcr-2018-

228711
}

\section{DESCRIPTION}

A 10-year-old boy presented with diminished vision in his right eye noted for 1 month. There was no history of prematurity. Family and systemic history was unremarkable. Best-corrected visual acuity (BCVA) was $20 / 120$ in the right eye with +6 dioptres sphere and $20 / 40$ in the left eye with +2 dioptres cylinder at $180^{\circ}$. Anterior segments were normal apart from the presence of inferonasal iris coloboma in both the eyes. The dilated fundus examination showed type III choroidal coloboma (Ida-Mann classification) in the right eye and type II choroidal coloboma in the left eye (figure 1A,B). Both eyes also had peripheral avascular retina separated by demarcation lines (arrows, figure $1 \mathrm{~A}, \mathrm{~B})$. Ultra-wide field fluorescein angiography (figure 1C,D) of both eyes revealed straightening of vascular arcades, supernumerary vascular branching and temporal avascular retina in both the eyes. A closer look at the macula revealed subfoveal choroidal neovascularisation (CNV, figure $2 \mathrm{~A})$, which was confirmed on swept source optical coherence tomography (figure 2A,B) and fluorescein angiography (figure 1C, arrow). A diagnosis of both eye choroidal colobomata with familial exudative vitreoretinopathy (FEVR) with right eye CNV was made and intravitreal bevacizumab was advised in the right eye.

At 1 month after intravitreal bevacizumab, the $\mathrm{CNV}$ had regressed (figure 2C,D) and BCVA improved to 20/60. The parents declined further injections and was advised regular follow-up. The visual acuity was

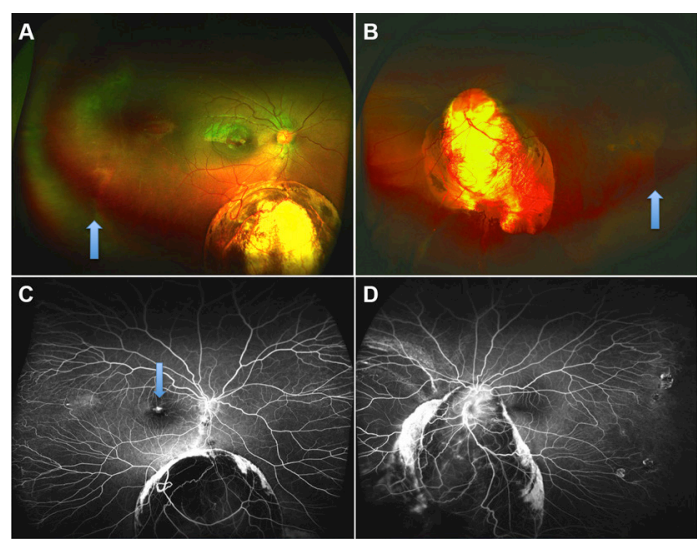

figure 1 UWF pseudo-colour photograph of the right (A) and the left eye (B) showing type-3 and type-2 choroidal coloboma respectively. The blue arrow marks line separating avascular peripheral retina from vascular retina. UWF fluorescein angiography $(C, D)$ revealed straightening of vascular arcades, supernumerary vascular branching and temporal avascular retina consistent with familial exudative vitreoretinopathy. Arrow in (C) shows choroidal neovascularisation.

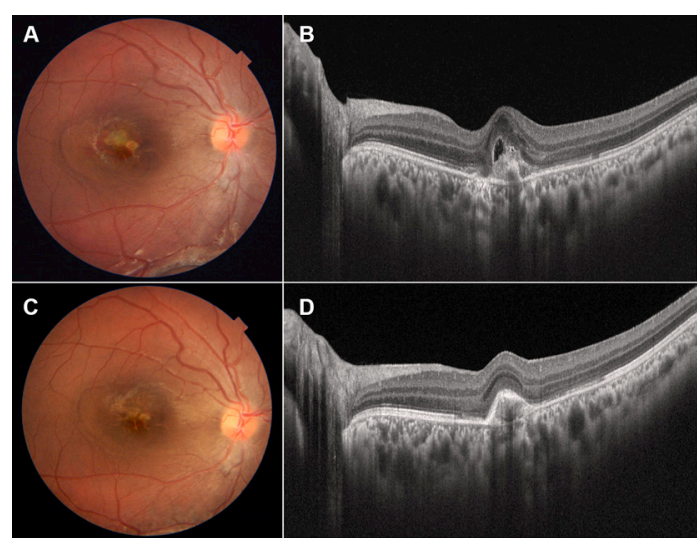

figure 2 Colour fundus photograph (A) and swept source optical coherence tomography (SS-OCT) (B) show choroidal neovascularisation at the macula of the right eye. At 1 month after intravitreal bevacizumab injection, fundus photograph and SS-OCT $(C, D)$ show resolution of intraretinal and subretinal fluid.

maintained at 6 months follow up with no signs of recurrence.

Familial exudative vitreoretinopathy is a bilateral asymmetric ocular hereditary disorder. It is characterised by peripheral avascular retina, neovascularisation and retinal detachment. About $50 \%$ of the cases can be linked to four causative genes FZD4, NDP, LRP5, and TSPAN12 which affect 'wnt' signalling pathway. Choroidal coloboma on the other hand occurs as a result of the failure of the embryonic fissure to close ${ }^{2}$ which can occur due to various genetic defects and environmental factors. The coloboma gene network developed from the genes associated ocular coloboma has sonic hedgehog and paired box 6 genes in the pivotal role. ${ }^{3}$ However, disruption of 'wnt' signalling pathway could also cause coloboma. ${ }^{4}$ An interaction of these genes may explain the coexistence of the FEVR with coloboma. CNV is a known rare complication associated with choroidal coloboma. ${ }^{5}$ This case highlights the occurrence of these two anomalies in a single patient which, to the best of our knowledge, has not been reported before.

\section{Learning points}

- Ultra-wide field angiography is useful for imaging of the peripheral retina, and it is particularly useful for providing panoramic images of the retina with a single click.

- Familial exudative vitreoretinopathy may also be associated with coloboma of the fundus. 
Ultra-wide field angiography is useful for imaging of the peripheral retina, and it is particularly useful for providing panoramic images of the retina with a single click. This is especially relevant in paediatric patients ${ }^{6}$ or patients with poor vision, where creating a montage image may be time-consuming and a source of discomfort to the patient.

Contributors VK, SKP: acquisition of data, concept, writing manuscript, review.

Funding The authors have not declared a specific grant for this research from any funding agency in the public, commercial or not-for-profit sectors.

Competing interests None declared.

Patient consent for publication Obtained.
Provenance and peer review Not commissioned; externally peer reviewed.

\section{REFERENCES}

1 Poulter JA, Davidson AE, Ali M, et al. Recessive mutations in TSPAN12 cause retinal dysplasia and severe familial exudative vitreoretinopathy (FEVR). Invest Ophthalmol Vis Sci 2012:53:2873-9.

2 Pagon RA. Ocular coloboma. Surv Ophthalmol 1981;25:223-36.

3 Moosajee M, Gregory-Evans CY. Advances in the molecular genetics of ocular coloboma. Expert Rev Ophthalmol 2006;1:209-27.

4 Zhou CJ, Molotkov A, Song L, et al. Ocular coloboma and dorsoventral neuroretinal patterning defects in Lrp6 mutant eyes. Dev Dyn 2008;237:3681-9.

5 Bhende M, Suganeswari G, Gopal L, et al. Choroidal neovascularization associated with coloboma of the choroid: a series of three cases. Indian J Ophthalmol 2011:59:148-51.

6 Kang KB, Wessel MM, Tong J, et al. Ultra-widefield imaging for the management of pediatric retinal diseases. J Pediatr Ophthalmol Strabismus 2013:50:282-8.

Copyright 2019 BMJ Publishing Group. All rights reserved. For permission to reuse any of this content visit

https://www.bmj.com/company/products-services/rights-and-licensing/permissions/

BMJ Case Report Fellows may re-use this article for personal use and teaching without any further permission.

Become a Fellow of BMJ Case Reports today and you can:

- Submit as many cases as you like

- Enjoy fast sympathetic peer review and rapid publication of accepted articles

- Access all the published articles

Re-use any of the published material for personal use and teaching without further permission

For information on Institutional Fellowships contact consortiasales@bmjgroup.com

Visit casereports.bmj.com for more articles like this and to become a Fellow 